\title{
En las cavernas (1912), de Emilia Pardo Bazán, con un breve panorama de la paleoficción literaria española
}

\author{
Mariano MARTÍN RODRÍGUEZ \\ Centrul de Cercetări Literare şi Enciclopedice [Centro de Investigaciones Literarias y \\ Enciclopédicas], Universitatea «Babeş-Bolyai», Cluj-Napoca \\ martioa@yahoo.com
}

\begin{abstract}
RESUMEN
Los descubrimientos paleontológicos realizados en el siglo XIX propiciaron el auge de un tipo de narraciones en que se trataba de reconstruir el modo de vida de los antepasados de la edad paleolítica. Este género también se cultivó en España. Emilia Pardo Bazán publicó en 1912 En las cavernas, que es una recreación hipotética, mediante la ficción, del origen del hombre y de su civilización desde un punto de vista ambiguo en lo referido a los supuestos beneficios de esa civilización, mediante la narración de las peripecias amorosas de una pareja paleolítica contrariada por su medio social. A esta importante obra de Pardo Bazán siguieron cuentos de escritores como Antonio de Hoyos y Vinent o José María Pemán, cuyas historias se pueden considerar también parábolas fantásticas sobre nuestros orígenes culturales. En cambio, novelas como El Rey de los Trogloditas (1925), de Jesús Carballo, perseguían conferir cierto realismo a sus fábulas de la cultura, sin olvidar su dimensión aventurera ni su significado alegórico. Posteriormente, la Guerra Civil de 1936 influyó en un nuevo planteamiento de la paleoficción española en la posguerra, a la que seguirá un período casi vacío para el género hasta la llegada de la novela prehistórica comercial.
\end{abstract}

Palabras clave: ficción prehistórica, parábola, civilización, Pardo Bazán.

\begin{abstract}
Paleontological discoveries made in the 19th century led to the rise of a type of fiction which tried to reconstruct the way of life of the ancestors of the Paleolithic age. This genre was also cultivated in Spain. Emilia Pardo Bazán published in 1912 In the Caverns, which hypothetically recreates, through fiction, the origins of mankind and civilization from an ambiguous point of view with regard to the supposed benefits of that civilization, by telling the love adventures of a Paleolithic couple upset by their social environment. This significant Pardo Bazán's work was followed by tales by other writers such as Antonio de Hoyos y Vinent and José María Pemán, whose stories can also be considered as fantastic parables about our cultural origins. In contrast, novels such as Jesús Carballo's The King of the Troglodytes (1925) aspired to infuse some realism into their cultural fables, without
\end{abstract}


neglecting their dimension of adventure. Subsequently, the Spanish War of 1936 influenced a new approach in the Spanish post-war prehistoric fiction, which was followed by decades with almost no Spanish works belonging to this genre until the arrival of the commercial long prehistoric fiction.

Key words: prehistoric fiction, parábola, civilization, Pardo Bazán.

Resulta llamativo el contraste entre la calidad internacional reconocida de la escuela paleontológica española, que puede enorgullecerse, ya en el siglo XIX, de descubrimientos tales como el del arte mural paleolítico de las cavernas gracias a los trabajos de Marcelino Sanz de Sautuola sobre Altamira, con la pobreza aparente de un género, el de la ficción prehistórica o paleoficción ${ }^{1}$. Ésta tiene su origen precisamente en la conjunción de los descubrimientos paleontológicos que fueron revelando la existencia de especies humanas anteriores a la nuestra, con una nueva visión de la historia de la Tierra que tendía a sustituir las viejas concepciones de la creación teológica por otras en las que el cambio constante de las condiciones naturales provocaba mutaciones correspondientes en los seres vivos, incluido el ser humano, tan sujeto al juego de la evolución como los demás animales. Aunque sería abusivo ligar estrechamente los avances científicos con la historia literaria, incluso en el caso de un género como la paleoficción, cuyos autores suelen esforzarse por

\footnotetext{
${ }^{1}$ La expresión «ficción prehistórica» parece lógicamente poco feliz, pues no hay manera de saber cómo hubo de ser la literatura antes del nacimiento de la escritura que marca el inicio de la Historia. No obstante, es la fórmula consagrada internacionalmente. Según N. Ruddik (2009), p. 1, constituyen la ficción prehistórica («prehistoric fiction») las «novels and stories about prehistoric human beings» [novelas y relatos sobre seres humanos prehistóricos]. Esta definición temática es perfectamente admisible si la ampliamos para que abarque las ficciones prehistóricas en forma de drama o de poema épico, que ciertamente existen, y será la denominación utilizada en este ensayo de ánimo sobre todo divulgativo, junto con la de «paleoficción», es decir, la ficción ambientada en el período Paleolítico. Aunque existen obras que se desarrollan en los períodos sucesivos del Mesolítico y el Neolítico, o incluso en las edades del cobre y del bronce, en el caso de que la región correspondiente no conociese la escritura ni hubiera entrado en la Historia gracias a los documentos escritos de sociedades ya históricas coetáneas, la ficción prehistórica por excelencia se ambienta en las primeras edades de piedra. Por esta razón, se suelen excluir las ficciones ambientadas en la protohistoria, como «El bermejino prehistórico o las salamandras azules» (1879), de Juan Valera. Pese a su título, este relato se enmarca más bien en la narrativa histórica arqueológica muy en boga en la segunda mitad del siglo XIX, desde Gustave Flaubert hasta Henryk Sienkiewicz. Por su parte, la leyenda dramática «La mujer muerta» (Cuentecillos al aire, 1898), de José Zahonero, presenta un mundo bestial parecido al de las primeras paleoficciones, incluida la ferocidad contra la mujer derivada de un patriarquismo belicista; sin embargo, la tribu es la protohistórica de los arévacos de la Meseta Central ibérica.
} 
dar la impresión de que se ajustan a los últimos descubrimientos en la materia, no cabe duda de que la continua aparición de fósiles, inclusive de homínidos, aguijó la imaginación de numerosos escritores europeos en la segunda mitad del siglo XIX. Estos tomaron como punto de partida las parcas informaciones que podían desprenderse científicamente de los escasos restos de épocas tan lejanas para crear mundos posibles arcaicos dotados del prestigio intelectual de los nuevos conocimientos, unos mundos en los que la fantasía evocadora ofrecía a los lectores un panorama vivo de los antepasados de la Edad de Piedra. Sin embargo, ese panorama ficticio solía obedecer más a las diversas convicciones ideológicas de los autores y de su público que al rigor de la ciencia, mientras que la pintura de los paisajes y las peripecias narradas no dudaban en transgredir los propios conocimientos de su tiempo en aras del efecto literario, de la necesidad de crear precisamente un universo ficticio autosuficiente y reconocible como tal, en el cual la ciencia se ponía al servicio del ejercicio de la imaginación e, incluso, de una nueva mitología construida mediante la literatura ${ }^{2}$. De hecho, la paleoficción no divulga lo que habría ocurrido realmente en la prehistoria, sino lo que el escritor y sus lectores convienen en que pudo ocurrir, es decir, una «prehistoria» generada a partir de cronotopos más que de datos estrictamente arqueológicos ${ }^{3}$. Ya en las primeras narraciones prehistóricas aparecían determinados motivos ${ }^{4}$ tanto temáticos

${ }^{2}$ Según M. Guillaumie (2006), p. 310, «[q]uand la science, chargée d’interpréter le réel, ne nous propose pour ancêtres que des fragments d'êtres muets, anonymes, séparés de nous par la barrière de l'animalité et pas des temps immenses, le RP leur en substitue d'autres, qui répondent mieux à nos attentes. [...] Il est en prise avec les grandes figures mythiques, avec les structures de l'imaginaire les plus anciennes et les plus enfouies» [cuando la ciencia, responsable de interpretar la realidad, solo nos ofrece como antepasados fragmentos de seres silenciosos, anónimos y separados de nosotros por la barrera de la animalidad y de tiempos inmensos, la novela prehistórica los sustituye por otros que responden mejor a nuestras expectativas. (...) Está en sintonía con las grandes figuras míticas, con las estructuras de la fantasía más antiguas y escondidas].

${ }^{3}$ Según J.-G. Rozoy (2008), p. 16, «la plupart des auteurs, en digne littéraires, sont plus qu'indifferents, et même rétifs, à la rigueur scientifique» [la mayoría de los autores, como buenos literatos, son más que indiferentes, si no reacios, al rigor científico], pese a lo cual dedica un extenso volumen a refutar los errores (pre)históricos, en general bastante graves, de un amplio corpus de paleoficciones estudiadas con bastante detalle.

${ }^{4}$ Una característica específica de la lectura de la ciencia ficción, aunque la noción es aplicable a cualquier tipo de ficción no mimética, sería, siguiendo a I. Langlet (2006), p. 8, que «les connaissances nécessaires à la compréhension du roman ne sont pas toutes à construire, pas à pas, au fil des aventures du personnage, mais elles sont aussi à puiser dans un stock identifié»» [los conocimientos necesarios para la comprensión de la novela no se tienen que construir todas paso a paso al hilo de las aventuras du personaje, sino que se deben extraer también de un acervo identificado]. Este acervo de temas, argumentos e, 
como argumentales inventados de aspecto mítico que constituyen el núcleo de la enciclopedia ficcional del género, el cual funcionó desde el principio de forma análoga a la ficción científica ${ }^{5}$, también cristalizada con sus características temáticas y de escritura por la misma época. Ambos tipos de literatura confiaban a la ciencia la impresión de verosimilitud de la invención mítico-fantástica y es esa ciencia a la que se recurría para solicitar al lector la necesaria suspensión de la incredulidad. A este respecto, no parece casualidad que los primeros grandes cultivadores de la paleoficción sean también conocidos por sus obras fictocientíficas.

En el mundo anglosajón sobresale Jack London, en quien puede observarse la influencia del socialdarwinismo en su imagen de la humanidad prehistórica, mientras que una visión menos ideologizada o filosófica y más preocupada por la recreación casi naturalista del mundo paleolítico caracteriza las novelas prehistóricas del belga J.-H. Rosny aîné y, en general, de la escuela francófona, siempre con las consabidas excepciones y salvedades. Sus narraciones prehistóricas se han seguido reeditando desde entonces y también fueron las que se tradujeron en España en ese primer período de la paleoficción. Así, Vamireh (1892), primera novela prehistórica de Rosny aîné, apareció con el mismo título, en traducción de José Velasco y García y con prólogo de Vicente Blasco Ibáñez en la editorial de

incluso, recursos formales, constituye la enciclopedia pragmática del receptor de ficciones y el procedimiento es perfectamente aplicable, mutatis mutandis, a la paleoficción.

5 Pese a que su objeto parecería relacionarla más bien con la ficción histórica, la paleoficción se basa en un procedimiento extrapolativo no disimilar al frecuente en la ciencia ficción. Afirma N. Ruddik (2009), p. 2, que «paleofiction is a speculative genre dependent on extrapolations from scientific or quasi-scientific discourse» [la paleoficción es un género especulativo que depende de extrapolaciones del discurso científico o cuasicientífico]. Y, más adelante, p. 3, «[b]oth sf [science fiction] and pf [prehistoric fiction] are speculative genres, although in slightly different ways. The logic of temporality [...] debars all witnesses to the future. In contrast, there were human witnesses to prehistory or we would not be here today. Yet there were no eyewitness accounts of prehistory: by definition, a surviving eyewitness account of an event signifies that history has begun. The prehistoric past and the future are both ultimately unknowable from the position of the present. The historic past, on the other hand, defined by its bequest of written documentation to the present, may be undecidable, but it is not unknowable» [tanto la ciencia ficción como la ficción prehistórica son géneros especulativos, aunque de forma algo diferente. La lógica de la temporalidad [...] excluye cualquier testigo del futuro. En cambio, hubo testigos humanos de la prehistoria o no estaríamos hoy aquí. Sin embargo, no hubo informes de testigos oculares de la prehistoria: por definición, el informe conservado del testigo de un acontecimiento significa que ha comenzado la historia. El pasado prehistórico y el futuro son, por lo tanto, incognoscibles en última instancia desde la perspectiva del presente. El pasado histórico, por otro lado, que se define por haber legado legado documentación escrita al presente, puede ser imposible de determinar, pero no es incognoscible]. 
este, Prometeo, en 1925. Un año después, la misma casa sacaba a la luz Antes de Adán (Before Adam, 1907), de Jack London, en traducción de Fernando Valera. Por su parte, la barcelonesa Seix Barral publicó en 1923 la novela prehistórica más conocida de Rosny, La conquista del fuego (La Guerre du feu, 1911), en versión de A. Ruiz y Pablo, y su continuación El león de las cavernas (Le Félin géant, 1918), en traducción de Rafael Marquina, en $1935^{6}$. Destaca la concentración de las versiones españolas en la década de 1920, como si el género, cuyos originales traducidos remontaban a décadas antes, por fin hubiera entrado en la conciencia literaria del país. Otros indicios de ello son los elogios a Rosny de Blasco Ibáñez, para quién aquel era «el indiscutible creador de la novela prehistórica» ${ }^{7}$, y, sobre todo, la aparición en 1928 de un artículo fundamental en el principal órgano de los intelectuales de aquel momento, la Revista de Occidente. Una «nota» del geógrafo e historiador José María Igual titulada «La novela prehistórica» presentó a los selectos lectores de la publicación de José Ortega y Gasset un panorama casi exhaustivo, pese a su brevedad. Igual mencionó sobre todo novelas prehistóricas en lengua francesa e inglesa, los idiomas principales del género, pero no omitió ejemplos alemanes e italianos hoy prácticamente olvidados ni dejó de dedicar el merecido lugar de honor a una novela danesa Brceen [El glaciar] (1908), de Johannes V. Jensen, a la que Igual consideró «la creación más acabada y perfecta» ${ }^{8}$ de la ficción prehistórica. Junto a Jensen, las otras dos grandes figuras resaltadas son las ya conocidas: Rosny, en quien vio el creador de verdaderas epopeyas del mundo primitivo, todo «simplicidad grandiosa y sabor de naturaleza»", y London, del que destacó la «originalidad y plástica psicológica» ${ }^{10}$ de su Antes de Adán. Tras prestar atención a dos novelas más recientes (ambas de 1925), Les Bisons d'argile [Los bisontes de arcilla], de Max Begouën, y La Fin d'un monde [El fin de un mundo], de Claude Anet, Igual abordó la ficción prehistórica como fruto de un «romanticismo vitalista» ${ }^{11}$ que aspiraba a una vuelta a lo primitivo como

\footnotetext{
${ }^{6}$ No nos constan otras traducciones del género publicadas en España antes de la Guerra Civil de 1936, de modo se ignoraron paleoficciones importantes histórica o literariamente como Rulaman (1875), de David Friedrich Weinland; Eymirah (1893), de Rosny aîné; The Story of $A b$ [La historia de Ab] (1897), de Stanley Waterloo; Daâh, le premier homme [Daah, el primer hombre] (1914), de Edmond Haraucourt; In the Morning of Time [En los albores del tiempo] (1912/1919), de Charles G. D. Douglas; Lovci mamutio [Los cazadores de mamuts] (1918) y otras paleoficciones de Eduard Štorch, o el poema narrativo The Great Feud (1926), de E. J. Pratt. Otras ficciones prehistóricas anteriores a la Gran Guerra se traducirían después de 1939, como veremos.

${ }^{7}$ V. Blasco Ibáñez (1933), p. 369.

${ }^{8}$ J. M. Igual (1928), p. 101.

${ }^{9}$ J. M. Igual (1928), p. 103.

${ }^{10}$ J. M. Igual (1928), p. 103.

${ }^{11}$ J. M. Igual (1928), p. 106.
} 
manifestación de un alma más anímica, en contraste tanto con el individualismo como con el colectivismo contemporáneos. Se trataría, pues, de un «amor romántico hacia el hombre auroral» ${ }^{12}$. Aparte de esta caracterización epocal seguramente discutible, al menos por lo vago de sus afirmaciones, al autor de este ensayo fundamental no se le escapó el paralelismo con la ficción científica que recordamos $^{13}$ :

En el siglo pasado, los grandes descubrimientos geográficos, así como los del laboratorio, motivaron la novela científica. La tierra, devolviendo al Sol culturas ancestrales, hizo nacer la novela prehistórica.

La alusión a la ficción científica tenía, además, la utilidad de contribuir a contextualizar la paleoficción en un universo literario entonces mejor asimilado en España, especialmente entre los novecentistas de la generación de Ortega, mientras que la novela prehistórica no mereció más atención que la prestada por Igual, seguramente como preparación de su antología de Lecturas prehistóricas, que anunció en su ensayo, aunque parece que nunca llegó a ver la luz. Por lo demás, la misma marginación de la paleoficción en España queda demostrada indirectamente por el hecho de que no mencionara ni un solo ejemplo en castellano, pese a su evidente conocimiento del tema. Sin embargo, en 1928 ya habían aparecido varias narraciones prehistóricas españolas cuyo olvido pudo deberse a que se trataba de cuentos en algunos casos y, cuando fueron narraciones más extensas, quizá al hecho de haberse editado en colecciones normalmente no comentadas en la prensa de la época, como la católica «Biblioteca Patria», que publicó la única novela relativamente extensa española de la que tenemos constancia en ese período, El Rey de los Trogloditas (1925), de Jesús Carballo, o en las colecciones periódicas que, desde El Cuento Semanal en 1907, ofrecían a un público de masas obras de extensión mediana (unas sesenta páginas) escritas por prácticamente todos los ingenios de entonces. Entre ellos, se contó una escritora que, en el marco de esas colecciones, supo renovar su escritura mediante la adopción de modelos genéricos entonces nuevos en España y que luego adquirirían gran predicamento, como la ficción policial (La gota de sangre, 1911]) o la fantasía artúrica (La última fada, 1916]). Muy lejos ya de las novelas naturalistas que le habían dado mayor fama, Emilia Pardo Bazán experimentó en ellas una clase de literatura muy alejada tanto de la narrativa de observación social y de costumbres culminante en su ciclo de Los pazos de Ulloa (1886-1887) como de la psicológica que había cultivado en su etapa decadentista en novelas como La quimera (1905), por ejemplo. Con esas novelas cortas, la autora se sumó a los escritores de su generación o más jóvenes que, sin

\footnotetext{
12 J. M. Igual (1928), p. 100.

${ }^{13}$ J. M. Igual (1928), p. 100.
} 
abandonar su inspiración en la vida cotidiana contemporánea en algunas de sus obras, proponían al público lector distintas alternativas exóticas dignificadas por escritores consagrados e inmersos en las polémicas intelectuales de su época. Por ejemplo, el oficio literario de London o Rosny aîné se manifestó también en unas paleoficciones cuyo estilo y preocupaciones coincidían con los de sus demás obras, incluidas las naturalistas, de modo que sus novelas responden a su universo creativo personal más que a los tópicos de la narrativa popular folletinesca dirigida exclusivamente a un público de masas de cultura limitada, tal como sugieren su estilo más elaborado y su interés por ofrecer una visión coherente y matizada en su simbolismo de los orígenes del hombre y de la civilización, que el estadounidense presentó a través de una óptica ambiguamente socialdarwinista, mientras que el francobelga parecía preferir a la imagen de la struggle for life [lucha por la vida] un mundo tendente en mayor medida a la colaboración y el equilibrio ecológico. Pardo Bazán, por su parte, ofreció un panorama de la prehistoria en que el punto de vista sobre todo antropológico de sus grandes predecesores en el género se sustituyó por otro de carácter más social e incluso político.

En su relato En las cavernas, aparecido en 1912 como segundo número de la colección periódica El Libro Popular ${ }^{14}$, Pardo Bazán no se refirió en absoluto a otras razas humanas distintas a la nuestra, ni discutió implícitamente la cuestión de los grados relativos de humanidad de unas y otras. Sus personajes son seres como nosotros y, como tales, amenazados por la violencia entre miembros de la misma especie, como se desprende de una alusión fugaz al principio del relato, cuando se menciona el largo viaje de una horda hacia un lugar «donde sus semejantes, los humanos, no fuesen más numerosos y fuertes y los exterminasen $\rangle^{15}$. No obstante, este potencial narrativo no se explota para generar una acción (pre)bélica, como ocurriría en bastantes de las paleoficciones españolas extensas posteriores. El enfrentamiento se produce en el interior de la horda, la cual aparece desde el primer capítulo fracturada entre diversas ideologías. Estas orientan marcan las líneas de tensión de la intriga y determinan el comportamiento de unos personajes que funcionan como vehículos simbólicos de las distintas posturas, al modo alegórico. Desde este punto de vista, «the short-story like simplicity of their characterisation ${ }^{16}$ [la simplicidad, propia de un relato, de su caracterización] no parece ser un defecto, sino una opción consciente, frecuente por lo demás en un género en que se solían ventilar sobre todo, como en la epopeya, destinos colectivos, que eran los de la especie, y no los individuales, por lo demás difíciles de reflejar de forma verosímil.

\footnotetext{
${ }^{14}$ Con ilustraciones estilizadas y bastante modernas de Luis Checa.

${ }^{15}$ E. Pardo Bazán (2002), p. 533.

${ }^{16}$ J. Biggane (2003), p. 141.
} 
Tampoco nos parece demasiado justo el reproche implícito en la afirmación de que «[t]he text contains a substantial amount of what might loosely referred to as historical costumbrismo, in which lengthy and detailed accounts of the tribe's way of life and customs are given ${ }^{17}$ [el texto contiene una cantidad importante de lo que se podría vagamente calificar de costumbrismo histórico, en el que se da cuenta larga y pormenorizada del modo de vida y las costumbres de la horda]. Aparte de la necesidad de cierto detalle en la descripción por el hecho mismo de que el mundo posible de la paleoficción debe construirse de forma lo más completa posible para poder ser entendido por unos lectores cuya sociedad es, a priori, muy diferente de la prehistórica, Pardo Bazán redujo precisamente al mínimo las escenas pintorescas que figuraban en prácticamente todas las novelas del género como cronotopos casi imprescindibles y que se limitan en su relato a dos cazas, las del oso de las cavernas en el capítulo II y la de la captura de los dos elefantes en el IV. Ambas cumplen la función de aportar una dimensión de aventura a una fábula en la que aquel costumbrismo fue uno de los procedimientos utilizados por la autora para conferir efecto de realidad humana al debate de ideas y mentalidades central en la economía del texto. Por ejemplo, asistimos a la fabricación de útiles de silicio, especialmente para la caza y la defensa, lo que constituye otro de los motivos típicos de la paleoficción de todas las épocas y que En las cavernas se convierte en ilustración de un contraste entre lo viejo y lo nuevo. Mientras que uno de los jóvenes empuña un cuchillo de sílex, la mayoría de sus compañeros prefiere utilizar simples

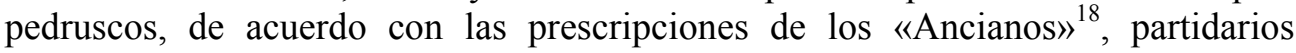
siempre de preservar en toda su pureza los usos de su juventud. Una vez muerto el oso, la escena de su descuartizamiento y reparto da pie a un nuevo contraste paralelo al anterior, pues «unos se agruparon en torno del fuego, repartiéndose, entre gruñidos de satisfacción, los trozos medio achicharrados de la carne; otros, bajo la luz lunar, se hartaban de vianda cruda, pingajos y piltrafas correosas» ${ }^{19}$. Es evidente que este costumbrismo es cualquier cosa menos realista, pues la autora estaría perfectamente al corriente de la imposibilidad de tal escena, dada la convivencia en un mismo lugar y tiempo de usos que los paleontólogos atribuían a períodos separados por muchos milenios, pero el rigor científico había de ceder el

\section{${ }_{17}^{17}$ J. Biggane (2003), p. 142.}

${ }^{18}$ El poder en la tribu lo ostentan los ancianos de la misma, de los dos sexos, aunque se alude a una etapa anterior de «matriarcado, que empezaba a caer en desuso» (p. 542). Por lo demás, tanto los varones como las mujeres de edad avanzada se comportan con el mismo conservadurismo. El feminismo de Pardo Bazán era lo bastante lúcido como para observar que las mujeres y los varones se comportan de forma parecida una vez en el poder. En cualquier caso, la dimensión propiamente de género nos parece secundaria en este relato respecto a la crítica antropológica de la civilización, aunque esta incluya naturalmente el tema de las relaciones familiares y de pareja como un elemento fundamental.

${ }^{19}$ E. Pardo Bazán (2002), p. 546. 
paso a las exigencias de la arquitectura conceptual de la fábula, a su efecto simbólico, y pocas cosas habrá más expresivas del contraste perseguido que esa convivencia de lo crudo y lo asado en la misma tribu. Además, el hecho de que los Ancianos defiendan un modo de ingestión mucho más difícil para ellos por mor de la tradición sugiere irónicamente la estupidez del respeto de las costumbres heredadas solo por ser antiguas, mientras que los personajes innovadores chocan con la resistencia de la masa, aunque esta los imite, sin dejar de criticarlos. A este respecto, parece significativa otra escena, igualmente costumbrista, aunque seguramente no demasiado típica de la paleoficción. Se trata de la del capítulo III en que las mozas de la horda se entregan al dulce placer de la maledicencia contra una de ella, Damara, que «siempre está discurriendo» ${ }^{20}$ y es la presumida que sustituye los adornos recibidos por otros nuevos, que osa vestirse cuando la costumbre dice que cubrirse es indecente, porque «no es honesto a la mujer inflamar, con adornos y vestidura, el capricho del varón ${ }^{21}$. Las mozas condenan el comportamiento de la joven inconformista, aunque también la imitan, pues la moda ya era irresistible en eras tan lejanas. Sus comentarios (y los de los Ancianos escandalizados) abundan en el relativismo de los valores morales en la sociedad. La validez de la mojigatería erótica victoriana quedaba gravemente comprometida al aparecer como inmoral en otro contexto. Además, Pardo Bazán no se limitó a ironizar sobre algo relativamente inocuo como era la cantidad de tela (o de corteza de árbol) que cubría la carne, siempre femenina ${ }^{22}$.

La inversión de valores afectaba al corazón de la sociedad al quedar cuestionados las relaciones de pareja y, por ende, la noción de familia. Damara es universalmente criticada por su negativa a participar en la comunidad sexual de la horda, que dictaba como deber la promiscuidad completa, esto es, la obligación moral de las mujeres de darse a quienes las desearan, sin reservarse para un único amante. En este contexto, esa negativa de la protagonista no solo era una osadía, sino que «podía calificarse de delito ya» ${ }^{23}$. En cambio, Damara deseaba «un varón

\footnotetext{
${ }^{20}$ E. Pardo Bazán (2002), p. 555.
}

${ }^{21}$ E. Pardo Bazán (2002), p. 538.

${ }^{22}$ Según Biggane (2003), p. 141, «[f]emale figures, however thinly characterised, are subject to visual inspection in a way that the male characters are not» [las figuras femeninas, por muy someramente caracterizadas que estén, están sujetas a la inspección visual como no lo están los personajes masculinos]. Es de suponer que una escritora no se atrevería entonces a ser demasiado explícita en su descripción erotizante del cuerpo masculino para no dar lugar a equívocos sobre su decencia personal, pero también se podría interpretar como una muestra indirecta de feminismo. Mientras que los autores masculinos de paleoficción se centran en héroes cuyo vigor heroico se manifiesta en su físico, Pardo Bazán focaliza las descripciones en la joven, como indicio indirecto de su papel tan protagonista como el del héroe varón.

${ }^{23}$ E. Pardo Bazán (2002), p. 547. 
nada más, para que, cuando me nazca un hijo, lleve el mismo nombre de quien le engendró» ${ }^{24}$, lo que parece constituir una alusión deliberadamente anacrónica a la obsesión decimonónica por la filiación legítima de la prole, por la pureza del apellido, que subyace a las numerosísimas novelas y dramas de adulterio de la época. Este grave quebranto de la costumbre margina a Damara dentro de la sociedad prehistórica evocada y puede explicar que el elegido de su corazón sea el llamado Napal, otro inconformista con el que forma una pareja escandalosamente monógama. El joven es también un innovador revolucionario, en el respeto de un reparto tradicional de roles. Mientras Damara innova en la esfera femenina del amor y la familia, su amante lo hace en las tradicionalmente masculinas del arte y el trabajo, al inventar la música junto con el instrumento de la flauta y, sobre todo, solucionar el problema fundamental de la horda, a saber, «la gazuza continua, jamás saciada $»^{25}$ gracias a su descubrimiento de la agricultura y la ganadería, además de la domesticación del lobo. También inventa la vivienda, pues piensa sustituir las cuevas por palafitos al aire libre, en «[c]ada cual residirá con su amada, con los hijos que nazcan de ella y de él, que sean cosa suya, sangre de su sangre» ${ }^{26}$. Aunque su idea al imaginarse en su papel de puro héroe cultural (no participa en la caza) sea obtener un rango dirigente en la tribu que le permita encauzar la vida de esta en el sentido que los lectores victorianos considerarían civilizado, se aviene a los deseos de Damara de huir solos a un paraíso bucólico de su propia hechura, entre las hierbas olorosas, los frutos silvestres y sus rebaños. Frente a la tentación del compromiso civil, se plantea así la alternativa de un apartamiento análogo al exaltado en la literatura pastoril, no sin haber donado antes los frutos de su ingenio inventivo a la tribu famélica, con la esperanza quizás de que algún día entienda las ventajas de lo nuevo. No obstante, la malignidad de la sociedad impide tal salida. Ni siquiera la prehistoria parecía estar libre de manipulaciones políticas y religiosas.

Una de las razones aducidas por Damara para convencer a Napal de la conveniencia de escapar a la presión constante de la horda es la enemistad de Ambila, el «mago». Los inventos del joven demostrarían la inanidad y la mentira de los conjuros del brujo, que en el relato se manifiestan sobre todo en la pintura naturalista de las cuevas, esto es, en otro cronotopo de la paleoficción, si bien con la originalidad de que no sea el artista el héroe cultural, sino su opuesto. Sin embargo, este don artístico es el único ejemplo de creatividad que muestra. Su inteligencia es de otro orden; la suya es una mente política, maestra en la manipulación. Ambila se sirve de la religión, del «transporte de las creencias que ya asomaban, envueltas en las mágicas evocaciones» ${ }^{27}$, para ejercer el verdadero poder. Son los mayores

${ }^{24}$ E. Pardo Bazán (2002), p. 534.

${ }^{25}$ E. Pardo Bazán (2002), p. 550.

${ }^{26}$ E. Pardo Bazán (2002), p. 552.

${ }^{27}$ E. Pardo Bazán (2002), p. 537. 
quienes mandan, «pero los genios me inspiran -dice-, y yo influyo en las decisiones de los ancianos, que creen seguir su capricho y siguen mi impulso ${ }^{28}$. Solo le falta conseguir el poder efectivo, para lo cual es lo suficientemente astuto como para darse cuenta del potencial de los inventos de la pareja protagonista $\mathrm{y}$, tras confiárselos Napal por ser el único capaz de comprenderlos, quiere atribuírselos y hacerse pasar por el genio al que todos acabarían venerando. Para ello, le basta azuzar a Ronero, un mozo que desea a Damara para él mismo, aunque en los términos aceptados de la comunidad sexual de la horda. Cuando la pareja se dispone a escapar, la aparición del rival celoso desencadena una pelea entre los varones que se salda con la muerte de ambos, a la que sucede el asesinato de Damara por Ambila, en un final luctuoso y espectacularmente sangriento no atípico en la narrativa de Pardo Bazán. Un último párrafo de la voz narradora comenta lo ocurrido y describe el mundo abierto por el crimen, político además de pasional, que habría dado pie a la civilización ${ }^{29}$ :

Y fue la primera vez que en la tribu se cometió un crimen pasional. Le siguieron otros muchos, pues habiendo el mago Ambila enseñado el cultivo del trigo y la confección del pan y el arte de edificar moradas - por lo cual se le veneró como una divinidad-, la tribu dejó de andar errante, y dio origen a pueblos agricultores y pastores, que abolieron el viejo rito, enemigo del Amor.

El cariz de esta civilización, inclusive en lo que respecta a la familia y el amor, sugiere la marcada ambigüedad de En las cavernas. Aunque las simpatías de los lectores parecen querer atraerse hacia la pareja civilizadora en la que se focaliza la intriga, gracias a su belleza física y moral y a sus intenciones claramente progresistas, no faltan matices inquietantes, como la vanidad de la mujer o la ambición de mando del varón. Además, los argumentos de los viejos conservadores son más sólidos de lo que su presentación como seres retrógrados un tanto ridículos podría hacer pensar. Ambila avisa del peligro de la exclusividad amorosa: «por la mujer, el hombre odiará a su semejante y se odiará a sí mismo» ${ }^{30}$. Esta frase aparentemente misógina no lo es en su contexto, porque Pardo Bazán se refiere en primer lugar a la pareja monógama y a la idea que entraña de posesión exclusiva, de propiedad de la mujer, la cual solía traducirse en crímenes pasionales (o de género) como el narrado al final de la obra, que no sería sino el primero («la primera vez») de una larga serie de maltratos femeninos que la autora condenaba sin duda. El respeto aparente de la moral victoriana oculta una reivindicación no solo feminista, sino también iconoclasta frente a la mentalidad al uso. Además, no escapan a esa iconoclastia ni la política ni la religión como instituciones combinadas y

${ }^{28}$ E. Pardo Bazán (2002), p. 566.

${ }^{29}$ E. Pardo Bazán (2002), p. 579.

${ }^{30}$ E. Pardo Bazán (2002), p. 570. 
simbolizadas en la negra figura del brujo, a la vez asesino y el verdadero civilizador en la práctica, a fin de cuentas. La pintura idílica (y utópica) de la civilización futura que hace Napal, con sus viviendas en hileras, con los campos cubiertos de grano, con sus ríos navegables y lavanderas púdicamente cubiertas, es también la civilización de los celos y los crímenes. Pardo Bazán insta tácitamente a los lectores a decidir con qué imagen quedarse, y de ahí la mencionada ambigüedad del relato, cuya alegoría no tiene un sentido unívoco, aunque sea ese posible sentido el que la estructura, pues se le supeditan todos sus elementos, desde los diálogos, que parecen adoptar a veces la forma de debates más que de conversaciones, hasta el tipo de mundo posible creado, en el cual las apariencias de realismo ocultan la elección de una perspectiva profundamente ahistórica y acientífica, lo que no quiere decir, por supuesto, que se oponga a los conocimientos de la época. La autora simplemente utiliza esos conocimientos para inventar un universo ficticio en que la hipotética realidad prehistórica se altera mediante la extrema concentración de fenómenos e innovaciones separados por decenas de miles de años y la redondez de la tierra en un único lugar y momento y en un puñado de personas, al efecto de configurar una parábola en vez de un informe narrativo realista en el sentido positivista del término. Aunque se ha afirmado que «[1]a Pardo Bazán no duda, por ejemplo, en remontarse hasta la prehistoria de la Altamira ibérica para narrativizar sus lecturas científicas ${ }^{31}$, lo cierto es que la ciencia solo le sirve de punto de partida para un propósito que dista mucho de la mera divulgación. En las cavernas se cuenta más bien entre las paleoficciones que recurren a una comprensión simbólica de muchos milenios en el tiempo relativamente breve de la intriga al efecto de poner de relieve el aspecto de proceso, de transformación civilizadora que constituye el objeto principal del apólogo. Es este rasgo el que distingue esencialmente esta clase de parábola prehistórica de la paleoficción arqueológica (aunque resulte ser más bien mítica) cultivada, por ejemplo, por Rosny aîné. Aunque el simbolismo de los personajes y de las peripecias sea también una característica destacada en las narraciones pretendidamente fieles a la realidad (pre)histórica, el desdén por la exactitud científica en aras de la visión conceptual es mucho más marcado en aquellas parábolas. De este modo, se podrían distinguir dos grandes tendencias en la paleoficción, la alegórica y la que se podría llamar realista, con todas las matizaciones y salvedades necesarias. Ambas tendencias tuvieron representación en España, aunque parece haber predominado la alegórica, tras el ejemplo ofrecido por la novela corta prehistórica muy original y digna de la pluma de Pardo Bazán, cuyo radicalismo crítico heredaría, despojándolo de la calculada ambigüedad de En las cavernas, un escritor famoso, o infame más bien para muchos en España a causa de su notorio tradicionalismo, que tal vez convendría

${ }^{31}$ D. Villanueva y J. M. González Herrán (2002), p. XVIII. 
matizar a la vista de relatos como el cuento prehistórico «Historia del buen rey Totem», subtitulado «Fragmento paleolítico».

José María Pemán lo publicó primero en el periódico conservador El Debate en una versión que modificaría ligeramente al pasar al volumen titulado Cuentos sin importancia (1926), junto con otras narraciones breves, algunas de las cuales también pueden constituir sorpresas para quien se limite a pensar en su monarquismo a ultranza y en el afecto literario que siempre le tuvo el franquismo, gracias al cual mantuvo un carácter de intocable que le permitió seguramente poder reeditar en plena dictadura tal colección, incluida esa historia del rey Totem que en tan mal lugar dejaba a las instituciones más respetables. Como corresponde a la época de auge de las vanguardias en que fue escrito, el relato no perseguía conseguir verosimilitud alguna, sino que se presentaba desde el principio como una fábula burlesca que asumía su literariedad ajena a la plausibilidad científica, al incurrir gozosamente en multitud de anacronismos. En efecto, y contraviniendo cualquier lógica prehistórica, el narrador recurre al artificio del documento encontrado, en este caso una piedra de la edad paleolítica que habría descifrado (sic!) y que estaría «llena de provechosas enseñanzas sobre los orígenes de muchas $\operatorname{cosas} »\rangle^{32}$. El documento no era sino la historia de Totem, un macho membrudo que, tras clavar unas estacas bajo una piel de mamut y meter dentro sus bienes, incluida una mujer, se había convertido, mediante ese acto, en «propietario»" ${ }^{33}$. Como también era el más fuerte y el más hábil en el manejo del hacha de piedra, también se le proclamó rey. Frente a su brutalidad, pronto aparece la figura tópica del héroe cultural paleolítico, Menoch, el elocuente (en los límites de los monosílabos) y artista que, gracias a la belleza de su palabra y al invento de la música, persuade al pueblo a rebelarse contra los tributos que debían entregar a Totem. La muchedumbre ataca la propiedad de Totem, pero en vez de derribarlo de su poder, se limita a saquear el escaso botín, lo que provoca pendencias y, por ende, que se pierda la causa popular. El rey estrangula a Menoch, pero se da cuenta de la fuerza del pueblo y propone una especie de democracia, en la que las piedras negras que son votos en su contra se tornan en blancas por el efecto amenazante del hacha de sílex. Totem, ya «Soberano de un Gobierno Popular» ${ }^{34}$, propone a un súbdito sustituir el tributo forzoso de sus cabras por un saco de cocos que el rey le entregaría en el futuro. El súbdito trueca el saco prometido por otros bienes, y los demás van haciendo transacciones parecidas, pero el saco está vacío. Ante la perspectiva de perder lo negociado, todos dan los cocos por existentes, de forma que la economía se pone en marcha basada en ese bien imaginario y Totem se convierte en el inventor del crédito. Ahí acaba el fragmento paleolítico, lo que el

${ }^{32}$ J. M. Pemán (2006), p. 127.
33 J. M. Pemán (2006), p. 127.
${ }^{34}$ J. M. Pemán (2006), p. 130. 
narrador lamenta ante sus lectores, porque, «como habréis notado, íbamos viendo avanzar ya la humanidad y entrar en la civilización» ${ }^{35}$, tras haber asistido al «origen de la oratoria, de los Gobiernos populares, del sufragio, del crédito y de mil cosas progresivas y trascendentales; y, de seguir, hubiéramos presenciado el origen de toda la civilización ${ }^{36}$. Esta se resiente de su origen, es claro, pero basta con «aceptar las cosas dócilmente y no preocuparse mucho de los orígenes y de los porqués ${ }^{37}$, es decir, con en seguir aceptando sumisamente la farsa de los cocos... En resumidas cuentas, habría que olvidarse tranquilamente del origen distópico de las instituciones civilizadas, sin rebelarse contra la explotación, basada en la fuerza y en el engaño, de la mayoría por la minoría o la entidad gobernante. La recomendación era evidentemente irónica. Como mínimo, parece más bien un llamamiento a la lucidez desde una perspectiva próxima a la acracia. No hay propiedad ni ejercicio del poder que no estén viciados desde su origen. Y, aunque solo se hable de los «Gobiernos populares», el hecho de que Totem sea un monarcadictador impide interpretar el cuento como un ataque contra la democracia liberal, de la que simplemente se predica que es inexistente en la práctica. La brutalidad con que trata Totem al pueblo y a la mujer no deja tampoco demasiado bien paradas las instituciones de poder unipersonal y carismático, tanto la monarquía absoluta como las dictaduras que ya estaban empezando a asolar Europa, incluida la España en que Francisco Franco se impuso por las armas, como Totem con su hacha. No obstante, el ataque es universal y se dirige a los principios. La insatisfacción con la civilización y su ordenamiento per se es patente, pues «para Pemán el origen del poder es la fuerza bruta y la sustancia de la política exitosa está en el engaño y la

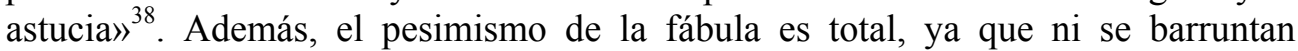
alternativas, cuyo utopismo ingenuo tal vez restara vigor a esta visión terrible de la humanidad, que solo el humor tragicómico de la escritura permite soportar e incluso apreciar como manifestación de una fantasía anarquizante y desengañada, una fantasía cuya planteamiento disparatado y de cierto aire vanguardista acierta a desarrollarse racionalmente hasta unas conclusiones que, no por hiperbólicas, dejan de reflejar esencialmente el simulacro supuesto por el orden del mundo real. De esta forma, la ficción prehistórica siguió sirviendo de vehículo al mito de los orígenes, pero al heró́smo civilizador, ya cuestionado por Pardo Bazán, sucedió su negación radical, una negación que, probablemente, no se podía llevar más lejos de lo que lo hacía esta parábola de negro humorismo.

«Historia del buen rey Totem» no fue el único cuento de este período en forma de apólogo paleoficticio. Un año después, Antonio Hoyos y Vinent publicó en la

35 J. M. Pemán (2006), pp. 131-132.

${ }^{36}$ J. M. Pemán (2006), p. 132.

${ }^{37}$ J. M. Pemán (2006), p. 132.

${ }^{38}$ A. S. Pérez-Bustamante Mourier (1999), p. 59. 
revista Por esos mundos, un cuento con un planteamiento similar, titulado «El traje milenario», en el que se narra, comprimido en la historia de una única pareja, cómo «[e]1 amor había hecho a $Y o^{39}$ hallar dos sorprendentes descubrimientos: el traje halagador de la vanidad femenina y la fidelidad del perro» ${ }^{40}$. Hoyos y Vinent desplegó ahí las gracias de su estilo ornado de raigambre decadentista y, pese a la brevedad del texto, consiguió crear un efecto de realidad ambiental estimable, pero su ambición no parece haber ido más allá de la muy respetable de entretener dignamente a sus lectores. En cambio, la intención pedagógica constituye un elemento muy a tener en cuenta en la primera novela prehistórica española extensa, la citada El rey de los trogloditas, del religioso y paleontólogo Jesús Carballo, publicada en 1925 y reeditada en mejores condiciones en 1936. Como señalan Fernández Palacios y Renero Arribas (1999), p. 751:

Su intención es la de facilitar a los jóvenes una visión sobre las costumbres de los primeros pobladores basándose, principalmente, en los recientes descubrimientos de la investigación arqueológica de la Provincia ${ }^{41}$-que él conocía de primera mano- y en lo que pensaba que podía aportar la Etnografía sobre sus costumbres. Todo ello es desarrollado mediante un estilo descriptivo, didáctico, plagado de mensajes morales dirigidos a los jóvenes.

De acuerdo con su propósito didáctico, destaca el detalle con que se describen la geografía del hábitat de los distintos pueblos de la cornisa cantábrica prehistórica que conviven y se enfrentan en la novela, pues las cuevas y los parajes corresponden a yacimientos arqueológicos entonces conocidos, de manera que la fábula cuenta con una localización de una precisión extrema y rayana en la pedantería ${ }^{42}$, aunque quizá deba interpretarse sobre todo como el resultado del

${ }^{39}$ Yo es un varón prehistórico, visto aquí como representante de la humanidad masculina y trabajadora.

${ }^{40}$ A. Hoyos y Vinent (2007), p. 92.

${ }^{41}$ Cantabria.

${ }^{42}$ En su brevísimo repaso de la ficción prehistórica española S. Vázquez de Parga (1991), p.

4, condena la novela de Carballo sobre todo por su «descarada exaltación patriótica [...]. El

P. Carballo, haciendo gala de la más mojigata patriotería, aplicó a una época en que el concepto de patria no se había inventado y España aún no existía, los topónimos actuales desambientando así su moralizante relato poblado de acartonados hombres prehistóricos cuyo comportamiento, sin embargo, parece muy cercano a nosotros». Al indignado comentarista no le falta parte de razón, aunque es a todas luces exagerado tildar la novela de exaltadamente patriótica, porque su mensaje hace hincapié en lo moral más que en lo nacional, estando también exenta de cualquier racialismo. También En las cavernas está ambientada en la antigua Iberia, pero es el único rasgo localista en una obra que adopta más bien la perspectiva universalista, antropológica, más común en el género. Más directamente nacionalista es, en cambio, La novela de España (1928), de Manuel Gómez Moreno, una 
patriotismo cultural de un autor que deseaba difundir la riqueza artística y arqueológica de su región. Los conocimientos arqueológicos también se respetan en lo posible, hasta el punto de que la novela parecería ajustarse a un realismo científico de índole positivista si no interviniera la imaginación y la ideología del escritor al reconstruir lo que la cultura material no podía indicar, es decir, la organización social, las costumbres y las creencias. Desde este punto de vista, Carballo no se caracterizó ahí por un clericalismo excesivo, ni por una propaganda religiosa sin duda anacrónica. La fe de los antecesores de la Edad de Piedra podía ser falsa, pero se describe con respeto. El anacronismo de la novela y, al mismo tiempo, lo que le confería actualidad, es su enfoque moral frente a los conflictos entre tribus que se suceden en ella. A diferencia de las paleoficciones alegorizantes que hemos recordado, El Rey de los Trogloditas no pretende narrar críticamente el origen de la civilización. Como en las novelas de aventuras prehistóricas de tipo realista, su mundo paleolítico es autosuficiente desde el punto de vista ficcional. Basta el atractivo de la reconstitución de un medio ilusoriamente verosímil y de las aventuras que viven los personajes en ese entorno supuestamente sancionado por la ciencia. En la novela de Carballo, esas aventuras son sobre todo de carácter bélico. Esto no es nada nuevo en el género, pero importa señalar que el socialdarwinismo racialista de mucha paleoficción anterior queda ya muy atrás. Los trogloditas no son antropoides brutales sedientos de sangre. Los enfrentamientos entre las tribus obedecen a causas muy humanas (el honor, el deseo de venganza por la muerte de familiares, la defensa del territorio e, inversamente, la tendencia expansionista de determinados grupos) y la guerra se lleva a cabo con todo el respeto debido a la estrategia militar. La principal novedad radica en que el protagonista Róbur, heredero de la jefatura de una tribu y huido ante la muerte de su padre por un usurpador, consigue su revancha, con la ayuda y la guía del anciano rey de la cueva de Altamira, pero su triunfo se traduce en el final del estado de guerra permanente gracias a su éxito al confederar las tribus. El pacifismo lúcido (existe una especie de garantía militar de la paz) constituye el verdadero progreso, frente a los avances

recreación mítica de la historia del país cuyo primer «ciclo» se dedica al Paleolítico en la Península Ibérica, desde los «preadamíes» (1974, p. 19) hasta la fundación de las primeras ciudades, en una sucesión de estampas simbólicas y estilísticamente modernistas (en el sentido hispánico del término) que configuran un Paleolítico idealizado como la «edad feliz» (p. 34) y teñido de religiosidad hasta el punto de que el mito de Adán y Eva se injerta en una prehistoria más poética que (ficto)científica. Una empresa parecida a la de Gómez Moreno, pero ampliada a la humanidad, como una especie de historia novelada del Hombre, es la acometida por Torcuato Luca de Tena en la novela Los hijos de la lluvia (a.C.) (1985), en el que un profesor moderno cuenta las memorias de sus vidas anteriores, desde la prehistoria recreada hábilmente de forma introspectiva en un ir y venir constante entre el presente y el pasado. 
materiales cuya insuficiencia había quedado trágicamente de manifiesto en la Gran Guerra $^{43}$. Como un anuncio prehistórico de la esperanza supuesta por la Sociedad de Naciones, la creación de la confederación entre las cuevas cantábricas «marca la más memorable fecha de la regeneración humana en aquellos remotísimos tiempos y el paso más gigantesco que en el sendero de la civilización ha dado la humanidad durante su infancia» ${ }^{44}$. A la vista de la historia, no parece que se hayan dado muchos nuevos pasos desde entonces. La Guerra Civil de 1936 y la Segunda Guerra Mundial vendrían concretamente a desmentir de la manera más trágica el optimismo humanitario de Carballo, justificando más bien la visión pesimista de la civilización manifiesta en las paleoficciones de Pardo Bazán o Pemán.

La doble crisis bélica no debió de ser ajena, de hecho, a la mutación de la ficción prehistórica española en la posguerra civil, en la que se publicaron varias novelas de aventuras cuyo planteamiento, realista y lleno de furia y violencia, prescindía del humor y la ironía de los ejemplos más logrados de la preguerra. Por ejemplo, la breve La tribu del halcón (1940), de Ricardo Baroja, presentó de forma algo maniquea ${ }^{45}$ la lucha sin cuartel de dos clanes en lo que parece ser una transposición voluntaria al Paleolítico superior vasco de la reciente guerra civil, como sugiere su subtítulo de «cuento prehistórico de actualidad» ${ }^{46}$. Por su parte, $E l$

${ }^{43}$ J. Carballo (1936), p. 206, alude directamente al barbarismo de una contienda que había demostrado la inanidad de las certidumbres positivistas del progreso y de la superioridad de la civilización moderna y blanca sobre lo primitivo al afirmar de la organización política de las sociedades prehistóricas que «[1]a elección, la herencia y los procedimientos de las civilizaciones modernas no se conocían todavía. Ni perdía nada con ello: ya que ahora con toda nuestra civilización tan ponderada hemos sufrido la más brutal, la más salvaje y la más odiosa de las guerras, la europea».

44 J. Carballo (1936), p. 185.

45 Según S. Aguiar Biaxauli (1998), p. 628, «[e]n La tribu del halcón, a través de las vicisitudes de dos tribus prehistóricas, que el autor quiere con ideales traspuestos de la actualidad, parecemos asistir a la lucha entre una ideología liberal, basada en el individuo y la libre competencia (la de la tribu del Halcón), y otra colectivista, con una distribución general de bienes y desconocimiento de la línea de sucesión entre padres e hijos, con comunidad de las mujeres y los niños -la de los Lobos-. Aunque Ricardo Baroja se inclina por la primera, a la que dota de todo tipo de cualidades positivas, frente a la segunda, adornada de multitud de defectos, prevé una síntesis superadora por unión física entre ambas; aunque sin especificar si se mantiene alguno de los presupuestos de la tribu vencida». Por su parte, Váquez de Parga la considera «[e]jemplificadora y moralizante» y alude a su «tono grandilocuente y engolado» (1993), p. 20.

${ }_{46}$ Por si cupiera alguna duda, el autor insiste en esta igualdad entre los primitivos y los supuestamente civilizados del siglo XX en la dedicatoria de esta breve novela a Julio Caro Baroja (1967, p. 590): "Yo, en este cuento, falto de datos, hago arbitrariamente pronunciarse a mis personajes cavernarios como si fueran contemporáneos y hasta civilizados. 
señor del fuego (1944), del escritor aún poco conocido M. Vallvé ${ }^{47}$ (Manuel Vallvé López), explotó en una narración bien escrita de aventuras bien llevadas las dicotomías heredadas de la vulgata intelectual decimonónica, al enfrentar al joven héroe solitario a razas humanoides más primitivas $\mathrm{y}$, sobre todo, a la figura del hombre monstruoso recaído en una animalidad atávica, caníbal y ladrón de mujeres, de aire gorilesco y ferocidad y fuerza sobrehumanas, al que el protagonista positivo vencerá gracias a su valor y sus cualidades de inteligencia humana, según un esquema consagrado por los preadanes de Jack London. Para encontrar una visión algo más pacífica, humanista, de la prehistoria, hay que esperar a Balok, el hombre que cazó al ruido (1946), de R. [Rafael] J. [Juan] Salvia, única novela de un autor que pronto renunció a la literatura por el cine, para desgracia de la literatura y del cine $^{48}$. Esta novela, que se desarrolla a finales del Paleolítico inferior, se esfuerza por llevar un mayor realismo, incluso psicológico, a la pintura de una sociedad primitiva, en la que el protagonista encarna la figura del genio incomprendido y marginado hasta el punto de quedar excluido de su tribu. El héroe, Balok, emprende entonces una odisea cultural para apresar el ruido, esto es, para dominarlo y ponerlo, como el fuego, al servicio de la humanidad. Su invención del tambor será el resultado y el efecto terrorífico de la percusión del nuevo instrumento inducirá tal terror a la tribu enemiga, que acaba huyendo justo cuando estaba a punto de vencer y aniquilar a la de Balok, en un genocidio que refleja, en los albores del ser humano, los que este había perpetrado pocos años antes de la publicación del libro de Salvia. No obstante, y aunque genere una considerable tensión narrativa, animando poderosamente la intriga, la violencia no tiene en esta novela el protagonismo casi absoluto que tiene en las de Baroja o Vallvé, pues Salvia se

Podrían mis muñecos, en vez de vestir pieles, ir cubiertos con paño azul horizonte o verde reseda, y disparar la ametralladora y el cañón de tiro rápido, en lugar de hacerlo con la honda y el arco [...]".

47 Vallvé, figura a la que no se ha prestado apenas atención, publicó en la misma editorial Molino en que apareció El señor del fuego varias novelas cortas de aventuras bajo el seudónimo de Adolfo Martí Caja, que pueden considerarse precedentes directos de los bolsilibros o novelas de a duro poco posteriores. Sin embargo, Vallvé no fue solo un novelista popular de la posguerra, ya que pertenecía a una generación mayor y su producción es, a la vez, más antigua y más amplia en registros. Además de novelas históricas como Los almogávares (1930), Vallvé se había distinguido como traductor y difusor literario, y no precisamente de los últimos éxitos norteamericanos, ya que había realizado adaptaciones para jóvenes de poemas como Os Lusíadas (1572), de Luís de Camões, con el título de Los lusíadas (1922), o del poema altomedieval anglosajón Beowulf, con el mismo título, en 1934.

48 Salvia inició en 1950 una exitosa carrera de guionista cinematográfico de comedias comerciales de un costumbrismo castizo y superficial, además de dirigir dos películas de la misma índole, Manolo, guardia urbano (1956) y Las chicas de la Cruz Roja (1958). Nada más lejos del compromiso literario e intelectual con una narrativa especulativa de calidad patente en Balok... 
centra a menudo en el personaje principal y en sus vivencias, en su tormento de pionero que barrunta oscuramente su creación. Además, se describe también su deseo erótico por la bella de su tribu, que se entregaba libre y con indiferencia a los mejores cazadores, hasta que lo hace también al torpe y soñador Balok, momento en que ambos descubren el amor e inician una relación monógama que recuerda a la de los protagonistas de En las cavernas, aunque no sabemos si Salvia leyó la paleoficción de Pardo Bazán. En cualquier caso, el autor más reciente presenta tal relación como un avance hacia una sociedad prehistórica menos bronca, en la que el tambor simboliza también el carácter fascinante y hasta pacificador del arte, en el camino de una civilización connotada positivamente, como en Carballo, aunque Salvia sea mucho menos ingenuo y bastante mejor artista, como acredita su prosa sobria y elegante, el conseguido efecto de realidad de su atmósfera y la habilidad de la estructuración de la intriga, por lo que S. Vázquez de Parga (1991), p. 4, ha podido afirmar que «Salvia une a la amenidad una precisa documentación científica, uniendo «la amenidad una precisa documentación científica».

Después de esta novela, la ficción prehistórica pareció dejar de interesar a los escritores españoles ${ }^{49}$. Que sepamos, la década de 1950 solo presenta un cuento catalán de Antoni Ribera titulado «El pacte», recogido en Llibre dels set somnis [Libro de los siete sueños] (1953), que narra en unas pocas páginas y en estilo coloquial, neorrealista incluso, la domesticación del perro. A esta breve parábola

\footnotetext{
${ }^{49}$ No faltaron, en cambio, las traducciones. Entre las obras publicadas entonces en España destacan las tres novelas prehistóricas de Johannes Vilhelm Jensen La tierra perdida (Det tabte Land, 1919), El glaciar (Brceen, 1908) y Norne-Goest (1919), incluidas en la edición de sus Obras escogidas (Madrid, Aguilar, 1956); «The Day Is Done» (1939; ...And Some Were Human, 1948), de Lester del Rey, relato traducido como «El fin de la raza» en el volumen ...Y algunos eran humanos (1957); Die Höhlen der großen Jäger (1953), de Hans Baumann, que apareció en 1957 con el título de Las cuevas de los grandes cazadores; The Inheritors (1955), de William Golding, novela fundamental traducida en 1968 como Los herederos; «Clonk Clonk» (The Scorpion God, 1971), también de Golding, que Ernestina de Champourcin incluyó en su traducción del volumen El dios escorpión (1973); What We Did to Father (1960) / The Evolution Man (1963), de Roy Lewis, paeloficción satírica y alegórica traducida como El fin del Pleistoceno (1976), y «La mort d'Odjigh» (Le Roi au masque d'or, 1892), de Marcel Schwob, cuento traducido como «La muerte de Odjigh» en El rey de la máscara de oro (1977). Varias paleoficciones importantes publicadas en el período comprendido entre la Segunda Guerra Mundial y la revelación de Jean M. Auel parecen haber quedado sin traducir al español, tales como el guion cinematográfico para leer Le Premier Amour [El primer amor] (1946), de Marcel Pagnol; una de las principales novelas en romanche, Culan da Crestaulta [Culan de Crestaulta] (1951), de Toni Halter; «Akho şi Tao» [Akho y Tao] (1963), de Ion Marin Sadoveanu; O Homem do Sambaqui [El hombre del conchal] (1975), de Stella Carr Ribeiro, e In grotta e in valle [En la gruta y en el valle] (1980), de Riccardo Bacchelli, limitándonos a las escritas en lenguas románicas.
} 
sucedieron algunas otras, tanto en catalán como en castellano, que prolongaron la característica tendencia alegórica de la paleoficción española, sobre todo de la breve. Pueden servir de ejemplo de ello dos cuentos publicados en 1989, «El inventor» (Amor siempre asediado y otros relatos), de Antonio Menchaca, que retoma el motivo ya tópico del héroe cultural incomprendido, y «L'infidel» (Barcelona 2080 i altres contes improbables), de Víctor Mora ${ }^{50}$, cuyo espíritu está más cercano a la iconoclastia del viejo relato de Pemán, aplicada esta vez al tema de las relaciones de pareja. Ambos relatos son, sin embargo, prolongaciones aisladas, supervivencias de un planteamiento paleoficticio moderno ajeno a las nuevas tendencias de la narrativa prehistórica políticamente correcta imperante en nuestro tiempo. Ese nuevo enfoque era ya completamente operativo en una de las escasas paleoficciones españolas del período posterior a la apertura del régimen franquista a partir de 1953, la novela juvenil ${ }^{51}$ Ut y las estrellas (1964), de Pilar Molina Llorente, que puede considerarse precursora, salvadas las diferencias de extensión, de la célebre saga paleolítico-sentimental titulada Earth's Children [Los hijos de la Tierra] (1980-2011; traducida en España a partir de 1985), de Jean M. Auel, que fue el ciclo que reactivó el género y lo ancló firmemente en el mundo de los superventas. Como no podía ser menos dado el carácter subalterno del país en el marco del mundo globalizado, este fenómeno de creación de novelas prehistóricas consensuales, en el sentido anglosajón del término, también llegó a España, donde varios autores se han especializado por primera vez en la paleoficción ${ }^{52}$, cultivándola con originalidad y habilidad variables dentro de las coordenadas internacionales del género en su vertiente más comercial. Entre las novelas de este siglo que podrían mencionarse, casi todas ellas de una extensión mucho mayor de lo que era habitual en la paleoficción decimonónica y moderna, destacan las de Antonio Pérez Henares que constituyen el ciclo de Nublares (El clan Nublares [2000], El ojo de la Garza [2002] y El último cazador [2008]), a la que se habría que sumar La mirada del lobo (2010); las de Lorenzo Mediano, quizá las más

${ }^{50}$ La versión castellana del propio autor se titula «El infiel» y se publicó en la sección Barcelona 2080 de su libro Cuentos del pasado reciente y de un futuro incierto (2011).

${ }^{51}$ Otras novelas prehistóricas publicadas en España en este período de vacío creativo para el género son también juveniles: la humorística Viatge al país del lacets [Viaje al país de los lacetos] (1969), de Sebastià Sorribas, y Tres xacals a la ciutat [Tres chacales en la ciudad] (1976), de Josep Vallverdú. También en catalán, Avel·lí Artís-Gener publicó en 1985 una novela de aire igualmente juvenil, aunque dirigida más bien a los adultos, titulada L'arriscada expedició dels pitecantrops del Montgrony [La arriesgada expedición de los pitecántropos del Montgroñ], en la que el autor hizo gala de su pericia narrativa y, sobre todo, de su humor e inventiva lingüística.

52 Nos limitamos a repasar la ficción prehistórica literaria. Sobre la paleoficción en la historieta, en España inclusive, se puede consultar con provecho el trabajo de G. Ruiz Zapatero (1997), por ejemplo. 
cercanas a la escritura habitual de los superventas, como El secreto de la diosa (2003), Tras la huella del hombre rojo (2005) y El espiritu del trigo (2007), y Al otro lado de la niebla (2005), del paleontólogo José Luis Arsuaga. En catalán, se puede recordar el díptico de novelas para jóvenes Gent de pedra [Gente de piedra] (2003) y La pedra del sol [La piedra del sol] (2006), de Carme J. Huertas. Las traducciones de novelas prehistóricas extranjeras también se suceden actualmente a ritmo sostenido. Sin embargo, este florecimiento del género se ha producido entre el desdén de la institución literaria oficial ${ }^{53}$. Este desdén se alía a la ignorancia, seguramente compartida por los mismos autores actuales de ficción prehistórica o paleoficción de la ya antigua tradición del género en la misma España ${ }^{54}$. Esta tradición no es tan rica como en las lenguas francesa o inglesa, pero atrajo a nombres indiscutibles del canon literario hispánico como Emilia Pardo Bazán, entre otros, y puede enorgullecerse de obras comparables con los clásicos de la paleoficción en otros idiomas, como En las cavernas, «Historia del buen rey Totem» o, incluso, Balok. Además, su escasez no le impidió presentar rasgos quizá originales en el panorama internacional del género en su primera gran época de desarrollo, como sería la preferencia por la parábola, el interés por las relaciones de pareja y, sobre todo, el frecuente escepticismo ante la llamada civilización, que las suele inmunizar contra los virus del racialismo y la dogmática acrítica del progreso subyacentes a tantos mitos de la ficción prehistórica convencional desde sus orígenes hasta nuestros días.

\section{Apendice:}

Ediciones de las ficciones prehistóricas españolas hasta 1936 localizadas (por orden cronológico de publicación):

53 La mayoría de las novelas prehistóricas traducidas después de 1980 son recientes, comerciales (en el sentido de que están escritas siguiendo las recetas del best-seller) y anglosajonas, salvo algún ejemplo contemporáneo francés como Sous le vent $d u$ monde (1997), de Pierre Pelot, traducido también en 1997 con el título de El viento del mundo. No obstante, se han traducido también algunos clásicos como «La Vendeuse d'ambre» (Cour double, 1897), de Marcel Schwob, con el título de «La vendedora de ámbar» en el volumen Corazón doble (1981); "The Grisly Folk» (1921), traducido como «Una raza aterradora» en La ciencia ficción de H. G. Wells (1987); Helgvor du Fleuve Bleu (1930), de Rosny aîné, como Helgvor, el guerrero del Río Azul (1991); "A Story of the Stone Age» (1897; Tales of Space and Time, 1899), también de Wells, como «Una historia de la Edad de Piedra» en Cuentos del espacio y del tiempo (2000), y Den svarta tigern (1978), de Björn Kurtén, cuya versión española, La danza del tigre (2001) se basó en la inglesa del propio autor (Dance of the Tiger, 1980).

${ }^{54}$ Por ejemplo, en el repaso bastante amplio de la paleoficción internacional hecho por $\mathrm{V}$. M. Fernández Martínez (1991) no se menciona ni un solo título original español. 
PARDO BAZÁn, Emilia: «En las cavernas», El Libro Popular, 2, 18 de julio de 1912.

CARballo, Jesús: El Rey de los Trogloditas (tiempos prehistóricos), Madrid, Biblioteca Patria, s/a (1925).

PEMÁn, José María: «El buen rey Totem», El Debate, 5 de mayo de 1925, p. 3.

Hoyos Y VINENT, Antonio. «El traje milenario», Por esos mundos, 11, 14 de marzo de 1926, pp. [9-14].

PEMÁN, José María: «El buen rey Totem», en Cuentos sin importancia, pp. 127133. Madrid, Voluntad, s/a (1926).

GÓMEZ-MORENO, Manuel: «Ciclo primero», La novela de España, pp. 15-62. Madrid, Antonio Marzo, 1928.

CARBAllo, Jesús: El Rey de los Trogloditas (tiempos prehistóricos), Santander, J. Martínez, 1936.

\section{Obras citadas}

Aguiar BiaXul, Silvia: La obra literaria de Ricardo Baroja, Madrid, Universidad Complutense, 1998 (sobre La tribu del halcón, pp. 319, 387, 489, 607, 628, 637, 697-698, 705, 737).

BAROJA, Ricardo: «La tribu del halcón», en Obras selectas, edición de Julio Caro Baroja, Madrid, Biblioteca Nueva, 1966, pp. 589-662.

Biggane, Julia: In a Liminal Space. The Novellas of Emilia Pardo Bazán, Durham, University of Durham, 2003 (sobre En las cavernas, pp. 139-142).

Blasco IBÁÑEZ, Vicente: «J. H. Rosny», en Estudios literarios, Valencia, Prometeo, 1933, pp. 366-375.

CARBAllo, Jesús: El Rey de los Trogloditas, Santander, J. Martínez, $1936^{2}$.

FERNÁNDEZ MARTÍNEZ, Víctor M.: «La Arqueología de la Imaginación: notas sobre Literatura y Prehistoria», Arqritica, 2 (1991), pp. 3-6.

FERNÁNDEZ PALACIOS, Fernando, y Víctor M. RENERO ARRIBAS: «Introducción a la obra novelística del prehistoriador Jesús Carballo: Presentación de un proyecto en marcha», Sautuola, VI (1999), pp. 739-759.

GÓMEZ-MORENO, Manuel: La novela de España, Gijón, Júcar, 1974.

GUILlaUMIE, Marc: Le Roman préhistorique: essai de définition d'un genre, essai d'histoire d'un mythe, Limoges, Presses Universitaires de Limoges, 2006.

Hoyos Y VINENT, Antonio de: «El traje milenario», Delirio, 1 (2007), pp. 85-92.

IGUAL, José María: «La novela prehistórica», Revista de Occidente, XXII, 64 (1928), pp. 100-106.

LANGLET, Irène: La Science-fiction. Lecture et poétique d'un genre littéraire, Paris, Armand Colin, 2006. 
PARDO BAZÁN, Emilia: «En las cavernas», en Obras completas, VI (Novelas cortas), edición de Darío Villanueva y José Manuel González Herrán, Madrid, Fundación José Antonio de Castro, 2002, pp. 529-579

Pemán, José María: «Historia del buen rey Totem», en Biblioteca Pemán, III Narrativa, edición de Ana Sofía Pérez Bustamente Mourier, Puerto Real, Grupo Joly, 2006, pp. 127-132.

PÉreZ-Bustamante Mourier, Ana Sofía: «Estudio preliminar», en José María Pemán, 24 cuentos de José María Pemán y «Nieve en Cádiz», Cádiz, Quorum Libros, 1999, pp. 11-80.

RozoY, J.-G.: Le Roman préhistorique: analyse critique, Charleville-Mézières, Bayart, 2008.

RUDDIK, Nicholas: The Fire in the Stone: Prehistoric Fiction from Charles Darwin to Jean M. Auel, Middletown, CT, Wesleyan University Press, 2009.

RUIZ ZAPATERO, Gonzalo: «Héroes de piedra: la prehistoria en el cómic», Complutum, 8 (1997), pp. 285-310.

VÁZQUEZ DE PARGA, Salvador: «Difusión y consolidación en España» [de la novela prehistórica], La Vanguardia, 3 de mayo de 1991, p. 4 (Libros).

VÁZQUEZ DE PARGA, Salvador: «La novela de ambiente prehistórico», CLIJ: Cuadernos de Literatura Infantil y Juvenil, 56 (1993), pp. 17-21.

VILlanueVA, Darío, y José Manuel GONZÁLEZ HeRRÁN: «Introducción», en Emilia Pardo Bazán, Obras completas, VI (Novelas cortas), Madrid, Fundación José Antonio de Castro, 2002, pp. IX-XXVII. 